OPEN ACCESS

Edited by:

Nathalie Van Vliet, Center for International Forestry

Research, Indonesia

Reviewed by:

Romain Duda,

Institut Pasteur, France

Miguel Farfan,

University of Málaga, Spain

*Correspondence:

Towa Olivier William Kamgaing wkamgaing@gmail.com

Specialty section:

This article was submitted to

Conservation,

a section of the journal

Frontiers in Ecology and Evolution

Received: 01 November 2018

Accepted: 14 June 2019

Published: 09 July 2019

Citation:

Kamgaing TOW, Dzefack ZCB and Yasuoka H (2019) Declining Ungulate Populations in an African Rainforest: Evidence From Local Knowledge, Ecological Surveys, and Bushmeat

Records. Front. Ecol. Evol. 7:249.

doi: 10.3389/fevo.2019.00249

\section{Declining Ungulate Populations in an African Rainforest: Evidence From Local Knowledge, Ecological Surveys, and Bushmeat Records}

\author{
Towa Olivier William Kamgaing ${ }^{1,2 *}$, Zeun's Célestin Brice Dzefack ${ }^{3}$ and Hirokazu Yasuoka ${ }^{1}$ \\ ${ }^{1}$ Center for African Area Studies, Kyoto University, Kyoto, Japan, ${ }^{2}$ School for the Training of Wildife Specialists, Ministry of \\ Forestry and Wildlife, Garoua, Cameroon, ${ }^{3}$ Department of Forestry, University of Dschang, Dschang, Cameroon
}

Sound wildlife management requires an awareness about the trends in animal composition and abundance by all stakeholders, including local peoples. Hunters ( $n$ $=255)$ from two adjacent community hunting zones $(\mathrm{CHZ})$ in southeast Cameroon were interviewed about the species composition of the animals killed using snare traps between 1952 and 2015-2016 and the drivers of change. The comparison of the perceived spatial and temporal trends in game composition to those from transect surveys and bushmeat records conducted in the area since the nineties evidenced the followings: (1) hunters are aware of the coarse changes in prey abundance, even for the species for which population density is difficult to estimate using more conventional survey methods; (2) in southeast Cameroon and in forests regions with similar fauna, the bay duiker (Cephalophus dorsalis) and the Peter's duiker (C. callipygus) are clearly more abundant than the white-bellied duiker (C. leucogaster) and black-fronted duiker (C. nigrifrons); (3) the two sites surveyed are at different stages of prey depletion, and (4) perception of prey composition is consistent with village-based bushmeat records and is likely to reflect more the species compositions in anthropogenic forest mosaics, where hunting is more frequent. Hunters' interviews constitute a valuable means to rapidly assess the status and trends in animal populations. However, the discrepancies between perceptions and prey composition in remote forest areas, combined with the assumption that shifting baseline syndrome is operating, highlight the need of caution when using local knowledge to generalize trends in fauna assemblages over large geographical and temporal scales.

Keywords: bushmeat hunting, Congo basin, forest duiker, local perception, species composition, snare trapping

\section{INTRODUCTION}

The meat of wild animals (known as "bushmeat") has long constituted an important source of proteins for forest-dwelling peoples in Africa (Mendelson et al., 2003). However, in many regions, patterns of bushmeat consumption, and trade are changing rapidly, mainly because of increasing demand from urban areas and declining supply in rapidly degrading locations (Fa et al., 2002). Historically, wild animals have been hunted in African forests with diverse "traditional" tools, including crossbows, nets, spears, and snares made of vegetal materials. Wire 
snares were introduced to Africa after the Second World War (Shetler, 2007; Yasuoka, 2014; Dounias, 2016). To date, the use of "traditional" hunting tools has considerably reduced in Central African rainforests whereas most productive tools, namely metallic snares and shotguns become widespread (Noss, 1998, 2000; Wilkie and Carpenter, 1999; Fa et al., 2005); (Kümpel, 2006).

The wide-spreading of cable snares and shotguns in Africa during the last decades has significantly contributed to the increase of hunting pressure although they are officially banned by forest codes in most countries (Noss, 1998; Wilkie and Carpenter, 1999; Fa et al., 2005; Fa and Brown, 2009). In southeast Cameroon, wire snares constitute the main hunting tool, providing 48 to $95 \%$ of the game (Dethier, 1995; Jeanmart, 1998; Muchaal and Ngandjui, 1999; Yasuoka, 2006; Bobo et al., 2015; Yasuoka et al., 2015; Duda et al., 2017).

Studies estimated the total harvest of wildlife in Afrotropical forests to be 1-5 million tons per annum (Wilkie and Carpenter, 1999; Fa et al., 2002). The increase in hunting puts disproportionate pressure in the vertebrate community, resulting in the alteration of his structure. Changes in vertebrate community structure can also alter many of the drivers of tree community dynamics by decreasing the abundance of largeseeded, mammal-dispersed plant species, and increasing the abundance of non-mammal-dispersed tree species (Nasi et al., 2008; Terborgh et al., 2008; Rosin and Poulsen, 2016). Mammals are the main targets of hunting and among them, rodents, and ungulates such as duikers largely constitute the most hunted taxonomic groups in terms of numbers and weight ( $\mathrm{Fa}$ et al., 2005). Large-bodied animals with low reproductive rates are the most vulnerable to hunting and therefore, the first to be extirpated from hunting forests (Nasi et al., 2008).

Estimating the level at which hunting becomes unsustainable remains challenging. Numerous authors have focused on forest duikers to evaluate the sustainability of hunting given their importance in Central Africa (Dethier, 1995; Muchaal and Ngandjui, 1999; Fimbel et al., 2000; Yasuoka, 2006; van Vliet and Nasi, 2008; Bobo et al., 2015). The Robinson and Redford's (1991) model is the most popular used. This model calculates the sustainable harvest level for a given population based on its population density. Dung survey along linear transects is the method most commonly used to estimate the population density of forest duikers in Central Africa (Fimbel et al., 2000; Lahm, 2001; Bobo et al., 2014; Jost Robinson et al., 2016) as this indirect observation method allows rapid population estimates over large and remote areas. However, compared to nocturnal surveys, dung counts are likely to underestimate the density of forest duikers (Waltert et al., 2006; Jost Robinson et al., 2016; Kamgaing et al., 2018). Also, the difficulty in distinguishing the dungs of different species living in the same area reduces the accuracy of estimates (van Vliet et al., 2008). Mediumsized duiker species (15-25 kg) are generally pooled into "red duikers" to improve the accuracy of density estimates. Hence, the sustainability of hunting for this group of species is often evaluated by considering them as a single taxon, obscuring the differential effects of hunting on individual species (Yasuoka, 2006; Bobo et al., 2015).
Other authors have used the species composition of the animals killed by local hunters as a proxy of the sustainability of hunting (Dethier, 1995; Yasuoka et al., 2015; Fa et al., 2016). In fact, prey composition is influenced by an associated history of hunting and can serve as a good indicator of the status of the surrounding fauna and hunting levels (Dethier, 1995; Bobo et al., 2015; Taylor et al., 2015). Information is available on bushmeat species composition across many sites in Central Africa (Fa et al., 2005, 2016; Taylor et al., 2015). However, although essential to enable the development of plans for conservation, dataset over time on prey composition and abundance is rarely available for the same site.

In this study, we use interviews to investigate the spatial and temporal patterns of changes in the composition of the animals killed using snare traps in two community hunting zones (CHZ) with contrasting hunting pressure and human population densities in southeast Cameroon. We also evaluate the reliability of local knowledge as a tool to assess the status and trends of multiple wildlife species over space and time. Although numerous studies have already proved the robustness of traditional ecological knowledge as a tool for management (Gandiwa, 2012; Pan et al., 2015; Nash et al., 2016; Brittain et al., 2018), our study contributes to improving the current knowledge on the state and trends in wildlife composition by integrating the spatial and temporal scales, although a similar study has been conducted in D.R. Congo (van Vliet et al., 2018). To facilitate comparisons with previous studies, we collated available data on interviews, bushmeat records and ecological surveys that were conducted in the same area since the nineties and contrasted the patterns in animal composition between different sources and time periods.

\section{MATERIALS AND METHODS The Study Area}

This study was conducted in CHZ 13 and 14, located in the northern periphery of Boumba-Bek and Nki National Parks, southeast Cameroon (Figure 1). The climate of the region is characterized as a four-season equatorial climate with a long dry season from December to February, and a short dry season in July-August. The major rainfall runs from September to November, and the minor rainfall is between March and June (Ekobo, 1998). The mean annual rainfall is $1,500 \mathrm{~mm}$ and the average temperature is $24^{\circ} \mathrm{C}$. The major vegetation type in the area is a mixture of evergreen and semi-deciduous forests (Letouzey, 1985).

The Baka and the Kunabembe (a Bantu-speaking population) are the main occupants of southeast Cameroon. Agriculture and harvest and trade of non-timber forest products are the main economic activities of both ethnic groups. The Baka have started subsistence farming several decades ago. Major food crops produced by the two ethnic groups are plantain, banana, and cassava whereas cocoa constitutes the principal cash crop, especially for the Kunabembe. Logging started in southeast Cameroon during the 1970's and gradually enabled the connection of remote villages to market areas. A logging road was built from Yokadouma to Biwala II, at the east side 


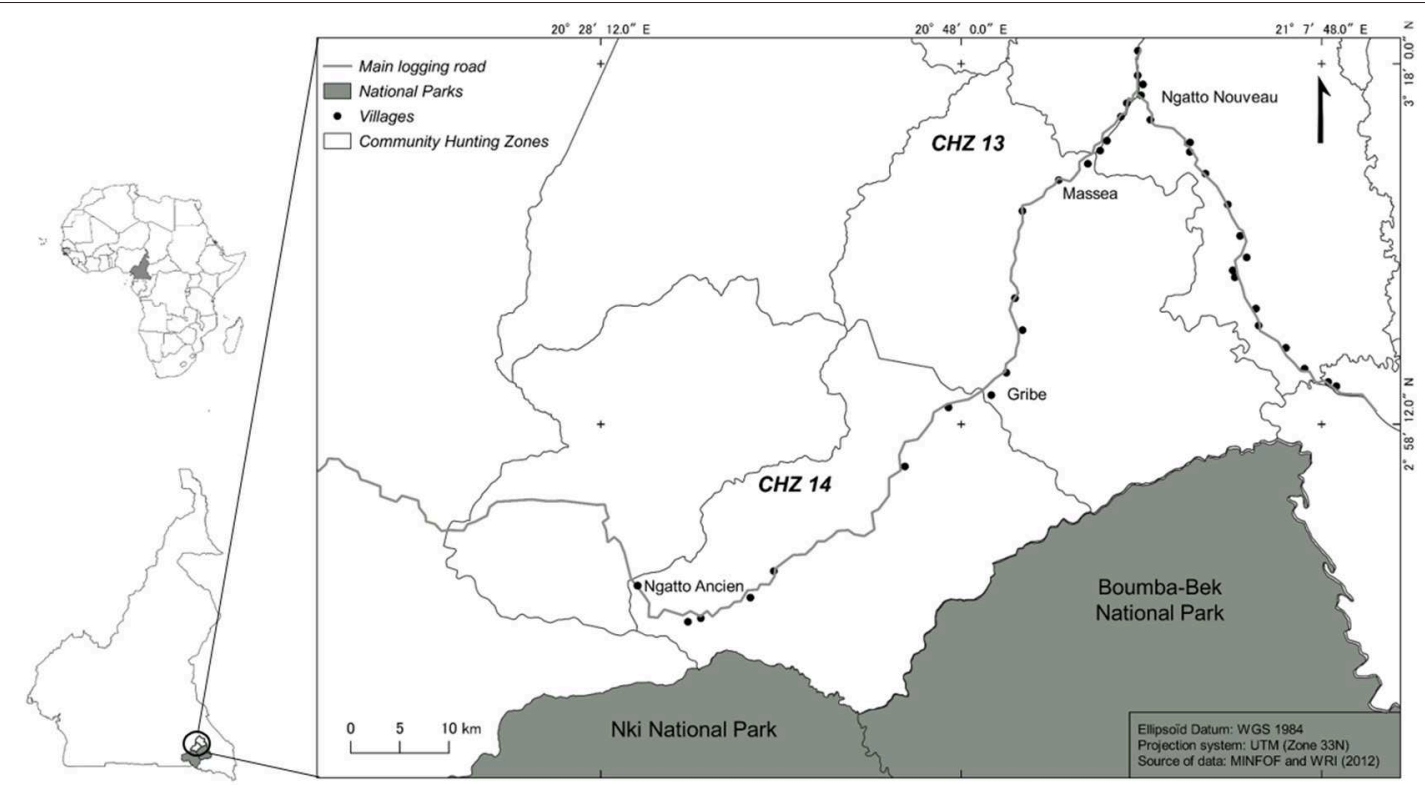

FIGURE 1 | Localization of the study area.

of Boumba river. Thereafter, part of the residents of "ancien" villages (located in $\mathrm{CHZ}$ 14) have deliberately migrated to disenclaved areas beyond the northeast of $\mathrm{CHZ} 13$ and have created the "nouveau" or new villages. According to two local informants in their forties, the road was opened up in $\mathrm{CHZ} 13$ in 1996, first up to Gribe. Thereafter, the road reached Malea Ancien, and stopped at the Bek river, which constitute the north boundary between Boumba-Bek and Nki National Parks. In the rest of CHZ 14, the road was opened in 2002 (Yasuoka, 2006). Human population size was estimated at 4,932 and 2,053 persons inside CHZ 13 and CHZ 14, respectively (Halle, 2000). CHZ 13 and CHZ 14 cover 111,824 and 86,822 ha respectively. Human population density in CHZ 13 is about two times as high as in $\mathrm{CHZ} 14$.

Community Hunting Zones (ZICGC or zones dintéret cynégetique à gestion communautaire) have been introduced in Cameroon in 1995 (Egbe, 2001). They constitute an attempt at a community-based management to ensure the conservation of wildlife resources by local people and allowing them to legally derive benefits from the exploitation of trophies. The management of a $\mathrm{CHZ}$ relies on an agreement between its neighboring communities and the wildlife administration. In practice, $\mathrm{CHZ}$ are co-managed by professional guides selected by the wildlife administration with members of the communities, organized into a COVAREF (Comité de valorisation des ressources fauniques). As in 2019, $14 \mathrm{CHZ}$ have been allocated to local peoples in southeast Cameroon.

\section{Data Collection}

Data on hunters' perception of prey composition was collected in June-July 2015, January-February, May-June, and SeptemberOctober 2016. Informants were selected based on their willingness and availability to contribute to the study. Ethical approval was not required in this study although it meets the ethical guidelines of the Social Research Association (2003). The study was prior informed. Before each interview, we stated explicitly that participation was free and that all information provided would be treated confidentially and anonymously. Verbal consent only was obtained from all informants as most speak French but could not write nor read any language. For informants under the age of 18 (4 out of 255), consent was given by their parents.

Hunters were asked to rank in order of importance the species most commonly killed by their snares in 2015-2016 and during their beginnings in hunting (1952-2009). In southeast Cameroon, most hunters get introduced to snares in their childhood. Young boys often use fiber materials to set "traps" just at the vicinity of village houses. Such activities may not be regarded as effective hunting, but rather as fun games (since children can mimic snaring as conducted by elders). We clarified to each informant that the "beginning in hunting" refers to the year when he effectively started setting snares for himself and, at a considerable distance from his village. This "subjective" qualification of hunting applies well to the settings of southeast Cameroon and probably to those of many other sites in Central Africa. Using it in the interview allowed a clearer understanding of the focus of this research by the informants i.e., hunting for livelihood (which is generally practiced from the adult age and at a certain distance in the forest, where preys are "present").

When the ranking of catch frequencies differed between the beginning in hunting and in 2015-2016, we asked the informants to cite the drivers of changes. To ensure representativeness, interviews were conducted in 9 out of 10 villages encompassing the two CHZ. Contrarily to the Kunabembe, most Baka did not know their age. We asked to those informants to cite one of their Kunabembe neighbors with whom they started primary school. 
We then visited the Kunabembe in question to asking his age and attributed the same age to the Baka.

In total, 255 hunters of whom 106 in CHZ 13 (43 Baka and 63 Kunabembe) and 149 in CHZ 14 (90 Baka and 59 Kunabembe) were interviewed. Informants were 16-74 years aged and had lived and hunted in the same area for most of their lives. All of them were males. Migrants were not included in our sample, guaranteeing that historical information provided on prey composition effectively reflected the context of the study area. Interviews were conducted primarily in French. Informants who could not speak French were interviewed in Baka or Kunabembe (the two local languages) with the aid of a local translator. To ensure correct communication, informants gave animal names in their respective native tongue (Table 1) and species were confirmed together with the data collection team using the pictures provided in the Kingdon field guide to African Mammals (Kingdon, 2015).

\section{Data Analysis}

Villages were categorized into CHZ 13 or CHZ 14 depending on their localization. Three villages were located in $\mathrm{CHZ} 13$

TABLE 1 | Species listed by hunters in southeast Cameroon as the mostly killed using snares and local names used for the interviews.

\begin{tabular}{|c|c|c|c|c|}
\hline $\begin{array}{l}\text { Species/group of } \\
\text { species }\end{array}$ & Scientific name & $\begin{array}{c}\text { Body } \\
\text { weight } \\
(\mathbf{k g})^{\star}\end{array}$ & $\begin{array}{l}\text { Local name } \\
\text { in Baka }\end{array}$ & $\begin{array}{l}\text { Local name } \\
\text { in } \\
\text { Kunabembe }\end{array}$ \\
\hline Giant pouched rat & $\begin{array}{l}\text { Cricetomys emini } \\
\text { (Wroughton, 1910) }\end{array}$ & $1.0-1.4$ & gbé & ntàh \\
\hline Tree pangolin & $\begin{array}{l}\text { Phataginus } \\
\text { tricupsis } \\
\text { (Rafinesque, 1820) }\end{array}$ & $1.6-3.0$ & kokòlo & zsغ̀l \\
\hline Brush-tailed porcupine & $\begin{array}{l}\text { Atherurus } \\
\text { africanus (Gray, } \\
1842)\end{array}$ & $2.5-4.0$ & mbòke & amiès \\
\hline Blue duiker & $\begin{array}{l}\text { Philantomba } \\
\text { monticola } \\
\text { (Thunberg, 1789) }\end{array}$ & $3.5-9.0$ & dغ̀ngbદ̀ & kuغ̀ \\
\hline Red duikers' group & / & / & / & / \\
\hline Black fronted duiker & $\begin{array}{l}\text { Cephalophus. } \\
\text { nigrifrons (Gray, } \\
\text { 1871) }\end{array}$ & $\begin{array}{l}14.0- \\
18.0\end{array}$ & mongala & sôp \\
\hline White-bellied duiker & $\begin{array}{l}\text { Cephalophus } \\
\text { leucogaster (Gray, } \\
\text { 1873) }\end{array}$ & $\begin{array}{l}15.0- \\
20.0\end{array}$ & monjombé & miغ̀ \\
\hline Bay duiker & $\begin{array}{l}\text { Cephalophus } \\
\text { dorsalis (Gray, } \\
1846 \text { ) }\end{array}$ & $\begin{array}{l}15.0- \\
24.5\end{array}$ & ngbomù & étsièn \\
\hline Peter's duiker & $\begin{array}{l}\text { Cephalophus } \\
\text { callipygus (Peter, } \\
1876)\end{array}$ & $\begin{array}{l}17.5- \\
25.2\end{array}$ & ngèndì & pirr \\
\hline Yellow-backed duiker & $\begin{array}{l}\text { Cephalophus } \\
\text { silvicultor (Afzelius, } \\
1815 \text { ) }\end{array}$ & $\begin{array}{l}45.0- \\
80.0\end{array}$ & bèmbà & édjam \\
\hline Red river hog & $\begin{array}{l}\text { Potamochoerus } \\
\text { porcus (Linnaeus, } \\
1758 \text { ) }\end{array}$ & $\begin{array}{l}45.0- \\
115.0\end{array}$ & pàmغ̀ & kô deuk \\
\hline
\end{tabular}

*Individual body weights are from Kingdon (2015).
(Massea, Zoka Diba, and Bintom) and six in CHZ 14 (Gribe, Song Ancien, Gouonepoum Ancien, Malea Ancien, Zoulabot Ancien, and Ngatto Ancien). Gribe, which is located at the selvage between the two CHZ, was classified in $\mathrm{CHZ} 14$ where its residents primarily carry out their hunting activities (Bobo et al., 2015).

We considered only the first four species perceived as the most common for analyses because from the fifth species cited, most informants seemed unsure. Hunters who could not remember the age at which they began hunting (21 Baka vs. 9 Kunabembe) were attributed the mean age at which other informants in their respective ethnic group started hunting ( $14 \pm 8$ years old for the Baka vs. $16 \pm 8$ for the Kunabembe). We used the ranking of catch frequencies by local hunters as a proxy for understanding wildlife changes through space and time. Statistical analyses were completed using the statistical software R (R Core Team, 2016). We used a chi-square test of independence $(\alpha=$ $0.05)$ to determine whether the ranking of catches significantly varied between the time period when informants effectively started snare hunting (1952-2009) and in 2015-2016, when data collection was carried out. Results of the interviews were compared with data from other interviews, bushmeat records, and mammal surveys conducted in southeast Cameroon since the nineties. We used diverse sources of information relative to large and medium-sized mammal abundance in this area (scientific papers, reports, and own unpublished data).

\section{RESULTS}

In average, informants effectively started snaring at $14 \pm 5$ years old and had experienced $22 \pm 11$ years in snaring (range: 3-51 years). About $21,25,50$, and $4 \%$ of the informants started snaring, respectively, between 1952-1989, 1990-1999, 2000-2009, and 2010-2014 (Table 2).

Overwhelming proportions of the informants (79\% in CHZ13 vs. $95 \%$ in $\mathrm{CHZ} 14$ ) reported that the current catch frequency of larger preys such as the red river hog (Potamoecherus porcus) and red duikers (Cephalophus spp.) is considerably low compared to the period between 1952 and 2009 (we excluded the informants who started hunting after 2009). However, $20 \%$ of the respondents in $\mathrm{CHZ} 13$ and 5\% in CHZ 14 did not perceive any substantial change in the composition of their catches over time and one informant (37 years old) in CHZ 13 reported that his

TABLE 2 | Distribution of hunters according to the period when they started snare hunting by themselves.

\begin{tabular}{lccc}
\hline Time period & CHZ 13 & CHZ 14 & Total \\
\hline $1952-1989$ & 28 & 26 & 54 \\
$1990-1999$ & 44 & 20 & 64 \\
$2000-2009$ & 28 & 100 & 128 \\
$2010-2014^{\star}$ & 6 & 3 & 9 \\
Total & 106 & 149 & 255 \\
\hline
\end{tabular}

*Because of low sample sizes in both CHZ, we excluded the time period [2010-2014] in Figures 2, 3. 
catch frequency has actually increased as he has developed more hunting skills throughout years.

Local hunters have attributed these declines to a number of factors (Table 3) including logging, which might make the animals "fleeing" to remote forest areas (77\% of informants in $\mathrm{CHZ} 13$ vs. $67 \%$ in $\mathrm{CHZ} 14 ; \mathrm{X}^{2}=0.39$, $\mathrm{df}=1, p=$ 0.533 ), overhunting ( 65 vs. $70 \%, X^{2}=0.99$, df $=1, p=0.319$ ), demographic growth (44 vs. $7 \%, \mathrm{X}^{2}=22.28, \mathrm{df}=1, p<0.001$ ), witchcraft ( 4 vs. $0 \%$ ), and farming ( 4 vs. $6 \%$ ). Two respondents in $\mathrm{CHZ} 14$ (one Baka and one Kunabembe) perceived that the decline in large preys resulted also from the restriction of their hunting grounds within smaller forest blocks, following the establishment of protected areas. Nine percent of the respondents in the CHZ 13 and $11 \%$ in $\mathrm{CHZ} 14$ had no opinion about the driver of prey alteration $\left(\mathrm{X}^{2}=0.2 \mathrm{df}=1, p=0.666\right)$. By ethnic groups, the main drivers of decline in larger game species were also logging (76\% Kunabembe; $70 \%$ Baka $\mathrm{X}^{2}=0.449 ; \mathrm{df}=1$, $p=0.503)$ and overhunting (57; 80\%; $\mathrm{X}^{2}=7.9 ; \mathrm{df}=1, p<$ $0.01)$. Compared to the semi-nomadic Baka (11\%), a significantly higher proportion of Kunabembe (46\%) perceived demographic growth as a major driver of prey alteration $\left(\mathrm{X}^{2}=28.2 ; \mathrm{df}=1, p\right.$ $<0.001)$. Thirteen percent of the Baka and $6 \%$ of the Kunabembe did not know why the composition of harvested animals has changed over time $\left(\mathrm{X}^{2}=1.7, \mathrm{df}=1, p=0.189\right)$.

In $\mathrm{CHZ} 13$, where human population density was higher, the species perceived to be the most commonly captured by snare hunters in 1952-2009 (Figures 2, 3) were the blue duiker Philantomba monticola (78\%), followed by the brush-tailed porcupine Atherurus africanus (55\%), bay duiker Cephalophus dorsalis (30\%), and Peters duiker C. callipygus (17\%). As in 20152016, significantly higher proportions of informants perceived the blue duiker $\left(93 \% ; \mathrm{X}^{2}=8.9\right.$; $\left.\mathrm{df}=1, p<0.005\right)$ to be the most frequent prey, followed by the brush-tailed porcupine $\left(71 \% ; \mathrm{X}^{2}=\right.$ 4.8; $\mathrm{df}=1, p<0.05)$. The Peter's duiker became the third most frequent prey $\left(40 \%, \mathrm{X}^{2}=11.8 ; \mathrm{df}=1, p<0.001\right)$ overtaking the bay duiker (27\%; $\mathrm{X}^{2}=0.1$; $\mathrm{df}=1, p=0.791$.). However, the tree pangolin Phataginus tricupsis, which was not among the main preys as in 1952-2009, became the fourth most common in 2015-2016 (24\%, $\mathrm{X}^{2}=1.00$; $\left.\mathrm{df}=1, p=0.318\right)$. Although not significant, the harvest frequency of the giant pouched rat Cricetomys emini has also increased between the two periods $\left(\mathrm{X}^{2}=3.4 ; \mathrm{df}=1, p=0.066\right)$. Fifteen percent and $13 \%$ of the hunters perceived, respectively, the red river hog and the yellowbacked duiker (Cephalophus silvicultor) to have been among the four most frequent preys in 1952-2009. However, only $3 \%\left(\mathrm{X}^{2}=\right.$ $8.1 ; \mathrm{df}=1, p<0.005)$ and $1 \%\left(\mathrm{X}^{2}=10.0 ; \mathrm{df}=1, p<0.005\right)$, respectively, perceived the same as for 2015-2016.

In $\mathrm{CHZ} 14$, where hunting pressure was lower, the blue duiker (54\%) was also the most common prey in 1952-2009. In contrast to $\mathrm{CHZ} 13$ (where the brush-tailed porcupine had already emerged as the second main quarry), the second most common prey in CHZ 14 was the Peter's duiker (32\%), followed by the bay duiker (34\%), and red river hog (24\%).

It is worth noting that perceived prey composition in CHZ 14 as in 2015-2016 is similar to the depiction made by hunters in the more heavily hunted CHZ 13 in 1952-2009. As in 2015-2016, higher proportions of informants in $\mathrm{CHZ} 14$ perceived the blue duiker to be the most common prey $\left(92 \% ; \mathrm{X}^{2}=51.9\right.$; $\mathrm{df}=1$, $p<0.001)$. The brush-tailed porcupine became the second most hunted species for a significantly higher proportion of informants ( $\left.58 \% ; \mathrm{X}^{2}=46.0 ; \mathrm{df}=1, p<0.001\right)$, followed by the bay duiker $\left(37 \% ; X^{2}=0.23 ; p=0.631\right)$, and the Peters duiker (perceived as the fourth most common catch by 5 and $15 \%$ of the informants in 1952-2009 and 2015-2016, respectively; $\mathrm{X}^{2}=8.01 ; \mathrm{df}=1$, $p<0.005)$. The proportion of informants who perceived the Peters duiker as the second most hunted game species has slightly decreased in 2015-2016 (26\%; $\mathrm{X}^{2}=1.3$; $\left.\mathrm{df}=1, p=0.254\right)$.

Compared to $\mathrm{CHZ} 13$, higher proportions of informants in CHZ 14 perceived, respectively, the red river hog (40\%) and the yellow-backed duiker (21\%) to be among the four most common preys in 1952-2009. However, only seven percent of the informants $\left(\mathrm{X}^{2}=56.7 ; \mathrm{df}=1, p<0.001\right)$ perceived the red river hog to still being common in 2015-2016, whereas the yellowbacked duiker had disappeared among the four principal preys.

\section{DISCUSSION}

The knowledge accumulated over generations by local people in the use of natural resources can provide valuable insights for sustainable management (Pan et al., 2015; Nash et al., 2016; Duda et al., 2017; Brittain et al., 2018; van Vliet et al., 2018). We analyzed the perceived state and trends in species composition of the animals killed using snare traps (here considered as a proxy for understanding wildlife changes through space and time) in two CHZ with contrasting human population densities in southeast Cameroon. Our approach combines spatial and temporal changes in prey composition as perceived by local hunters themselves with the trends from ecological and ethnographic surveys of hunted species.

\section{Perceived Trends in the Composition of Hunting Catches}

If we assume that a perceived regression in the catch frequency of a given animal species indicates a reduction in its abundance, a reported increase in the catch frequency would not necessarily imply an increase in its population abundance, but rather a growing hunting pressure on that population.

Informants in both $\mathrm{CHZ}$ claimed to harvest smaller prey species such as the blue duiker, porcupine, and giant pouched rat more frequently in 2015-2016 than in 1952-2009. However, substantial declines in the catches of larger bushmeat species were reported, especially in CHZ 14 where anthropogenic pressure was lower. Among the catches, the red river hog, the yellowbacked duiker, and red duikers had the sharpest declines. The white-bellied duiker (Cephalophus leucogaster), the black-fronted duiker (Cephalophus nigrifrons), and the yellow-backed duiker are extremely scarce or have almost disappeared among the catches. These results provide further evidence that hunting in southeast Cameroon has resulted in an increase of the proportion of blue duikers killed in snare traps and a decline in the proportion of red duikers (Dethier, 1995; Jeanmart, 1998; Yasuoka et al., 2015). 
TABLE 3 | Perceived drivers of declines in larger bushmeat species by ethnic group and by community hunting zone (CHZ) in Southeast Cameroon.

\begin{tabular}{|c|c|c|c|c|c|c|c|c|}
\hline \multirow[t]{2}{*}{ Perceived driver of change } & \multicolumn{4}{|c|}{ Proportion by ethnic group } & \multicolumn{4}{|c|}{ Proportion by $\mathrm{CHZ}$} \\
\hline & Baka $(n=103)$ & Kunabembe $(n=77)$ & $x^{2}$ & $p$-value & $\mathrm{CHZ} 13(n=106)$ & $\mathrm{CHZ} 14(n=74)$ & $x^{2}$ & $p$-value \\
\hline Main logging road & 0.20 & 0.30 & 1.722 & 0.190 & 0.22 & 0.27 & 0.675 & 0.412 \\
\hline Noise & 0.33 & 0.23 & 1.424 & 0.233 & 0.30 & 0.26 & 0.071 & 0.790 \\
\hline Overhunting & 0.57 & 0.80 & 7.886 & 0.005 & 0.65 & 0.70 & 0.992 & 0.319 \\
\hline Demographic growth & 0.11 & 0.46 & 28.243 & $<0.001$ & 0.44 & 0.07 & 22.280 & $<0.001$ \\
\hline Hunting by immigrants & 0.02 & 0.13 & / & / & 0.13 & 0.00 & / & / \\
\hline Farming & 0.02 & 0.07 & / & / & 0.04 & 0.06 & / & / \\
\hline Witchcraft & 0.02 & 0.01 & / & / & 0.04 & 0.00 & / & / \\
\hline Local development & & 0.04 & / & / & & 0.00 & / & / \\
\hline Lack of alternative proteins & & 0.01 & / & / & & 0.00 & / & / \\
\hline Poverty & & 0.01 & / & / & & 0.00 & / & / \\
\hline No opinion & 0.13 & 0.06 & 1.726 & 0.189 & 0.09 & 0.11 & 0.186 & 0.666 \\
\hline
\end{tabular}

Total proportions exceeds 1.00 because respondents were allowed to give multiple answers. $d f=1$ for all analyses. Bold values indicate significant differences between groups $(\alpha=0.05)$.

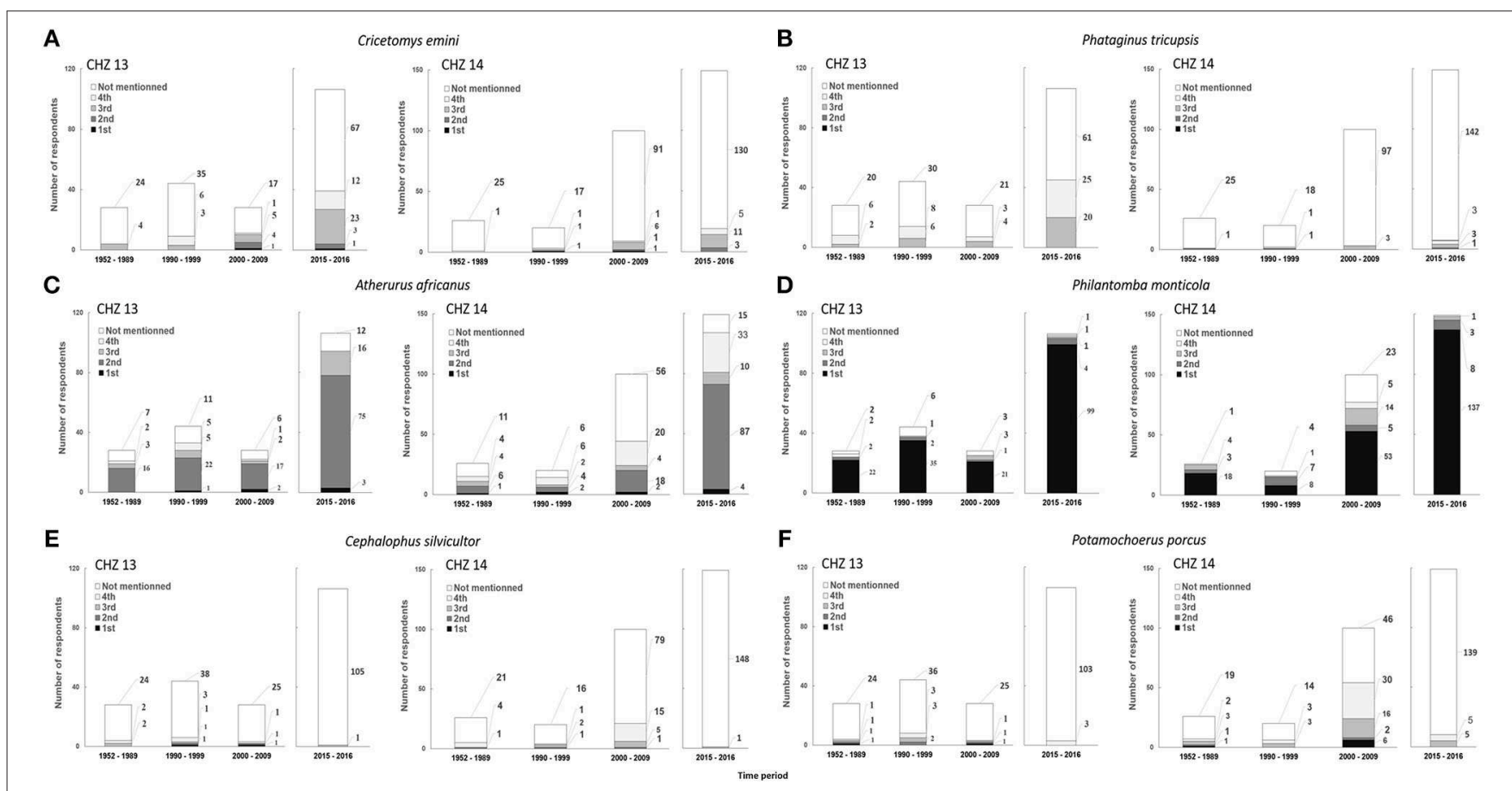

FIGURE 2 | Relative abundance of (A) giant pouched rat, (B) tree pangolin, (C) brush-tailed porcupine, (D) blue duiker, (E) yellow-backed duiker, and (F) red river hog in hunting catches between 1952 and 2016 in CHZ 13 (left) and in CHZ 14 (right). Because of low sample sizes in both CHZ, we excluded the time period $2010-2014$. 


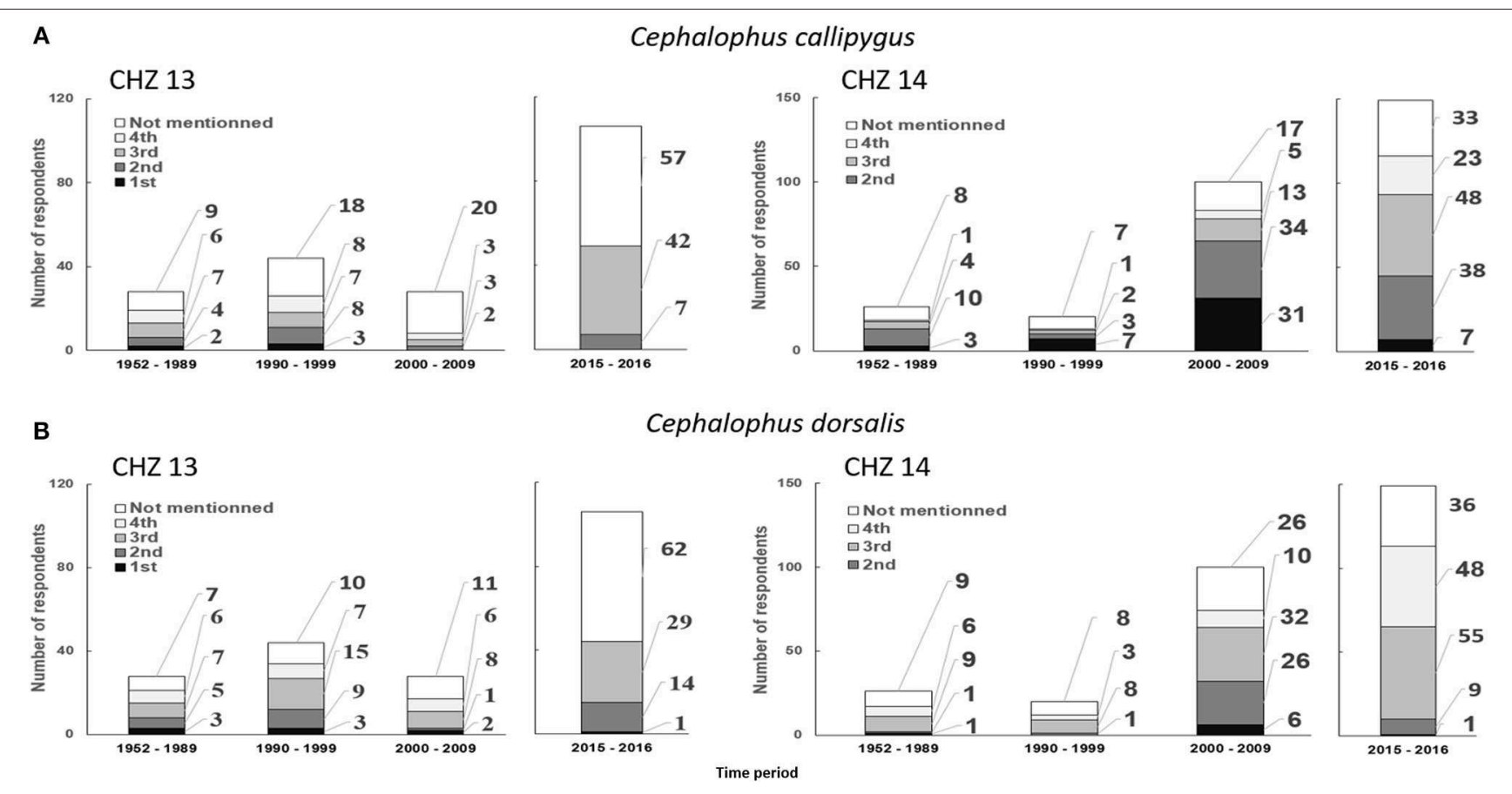

FIGURE 3 | Relative abundance of (A) Peter's duiker and (B) bay duiker in hunting catches between 1952 and 2016 in CHZ 13 (left) and in CHZ 14 (right). Because of low sample sizes in both $\mathrm{CHZ}$, we excluded the time period 2010-2014.

Why the perceived decline of larger species is not greater in the area of higher anthropogenic pressure is an interesting question, which suggests the existence of shifting baseline syndrome (SBS) as a potential explanation of the perceived differences. SBS can be described as a psychological and social phenomenon whereby each new human generation conceives as normal or as a reference the situation in which it was raised, due to a lack of experience, knowledge, and/or memory (Pauly, 1995; Bonebrake et al., 2010). Simply put, the concept refers to the loss of perception of change which occurs when a new generation redefines new norms. Therefore, local perception of prey profiles in 1952-2009 does not reconstruct the initial state of prey assemblages/species abundance, but attempts at depicting its depletion level during that period, a level which informants might consider as normal.

Thus, declines in larger preys were more difficult to perceive in the heavily hunted CHZ 13 because during our study period, populations of larger game species had already considerably reduced, probably as a result of logging and overhunting. The more a species was rare, the more it was difficult to perceive any change in its catch frequency, especially for the younger hunters. This type of SBS is otherwise referred to "generational amnesia" (Kahn and Kellert, 2002; Papworth et al., 2009). However, in CHZ 14, where logging was relatively recent (Yasuoka, 2006) and populations of larger game species considerably more abundant (Bobo et al., 2015), wildlife declines might be more recent. Consequently, perceiving the temporal changes in the catches of larger animal species could have been somewhat easier to local peoples, including the younger hunters.

Independently to whether the arguments developed above apply to the settings of our study area or not, remembering ancient hunting activities with accuracy could be difficult, especially for the oldest informants. Memory recalls of hunting returns could also be biased, since this activity in its essence may be influenced by narratives of declines, which create "false memories" or "memory illusions" (Hyman and Pentland, 1996; Roediger et al., 1996). In conclusion, perceptions of past prey profiles, which represent what some informants think and/or relate, might constitute a relatively altered vision of the real.

Hunting may affect different species of red duikers differently. Beside the blue duiker (Philantomba monticola) and the yellowbacked duiker (Cephalophus silvicultor), four duiker species grouped as "red duikers" (Cephalophus callipygus, C. dorsalis, C. leucogaster, and C. nigrifrons) live in southeast Cameroon (Ekobo, 1998). In both $\mathrm{CHZ}$, the latter two were cited as among the four main preys by $<4 \%$ of the hunters during their beginnings in hunting. Only $1 \%$ of the hunters in $\mathrm{CHZ}$ 14 mentioned them among their most common preys in 20152016 whereas they have disappeared among the main catches in CHZ 13. Kingdon (2015) argued that the white-bellied duiker is also the least commonly killed duiker in the D.R. Congo and probably the less abundant. In contrast, the two other species of red duikers (Peter's duiker and bay duiker) were perceived to have always been among the four main catches, despite the perceived retrogression in their ranking position, as reported earlier. In the two study sites, the levels of perception of Peter's duiker as being among the four top preys remained similar between the two periods (CHZ 13: $52 \%$ in $1952-2009$ vs. $46 \%$ in $2015-$ 2016, $\mathrm{X}^{2}=0.0$; $\left.\mathrm{df}=1, p=1.0\right)$; $\mathrm{CHZ} 14: 79$ vs. $78 \%, \mathrm{X}^{2}=$ 0.7 ; $\mathrm{df}=1, p=0.405)$. In $\mathrm{CHZ} 13$, the bay duiker was cited as among the main preys by 73 and $42 \%$ of the informants in 
1952-2009 and in 2015-2016, respectively $\left(X^{2}=19.7\right.$; $\mathrm{df}=1$, $p<0.001)$. In $\mathrm{CHZ} 14$, this game species was among the main preys of $70 \%$ of the informants in $1952-2009$ and $76 \%$ in $2015-$ $2016\left(\mathrm{X}^{2}=1.1 ; \mathrm{df}=1, p=0.298\right.$. $)$. A possible explanation of the differences in catch frequencies is that in southeast Cameroon, the black-fronted duiker and the white-bellied duiker might be naturally less abundant as reflected in hunting catches (Dethier, 1995; Yasuoka, 2006; Bobo et al., 2015; Duda et al., 2017). Another is that these four medium-sized duiker species existed at higher densities in the past, but the effect of hunting has been more severe on the black-fronted duiker and the white-bellied duiker.

Hunting can also affect the same species differently between different sites. For example, in northeast Gabon (where the same group of red duikers living in southeast Cameroon co-exist), nocturnal transect surveys conducted in the eighties shown that among duikers, the white-bellied duiker and the black-fronted duiker were naturally the least abundant (Feer, 1988). The blue duiker was largely the most abundant, followed by the bay duiker and Peters' duiker. However, van Vliet et al. (2007) repeated the surveys after two decades and concluded that the blue duiker remained the most abundant, but the bay duiker was depleted as a result of hunting, while the Peters' duiker was still withstanding the hunting level. Similarly, interview data have shown that in Baka villages around Lomié and Messok (more densely humanpopulated areas in southeast Cameroon), contrarily to the whitebellied duiker and the black-fronted duiker, only the blue duiker, followed by the Peter's duiker and the bay duiker still appear among duiker catches (Duda et al., 2017).

\section{Trends From Density Estimates and Bushmeat Records}

As far as we know, empirical density variations of hunted species over time have not been examined in southeast Cameroon. However, studies indicate that in Central Africa, reductions in mammal densities between unhunted and hunted sites can vary between 13 and 100\% (Fimbel et al., 2000; Hart, 2000; Lahm, 2001). As for today, at least five publications of mammal density estimates are available in the Boumba-Bek and Nki area. Out of them, one was carried out in the nineties (Ekobo, 1998), two in the 2000's (Bene Bene and Nzooh-Dongmo, 2005; Nzooh Dongmo et al., 2006), and two in the 2010's (Bobo et al., 2014; Kamgaing et al., 2018).

These studies used dung surveys and estimated higher population densities for red duikers. (2.5-20.0 animals $\mathrm{km}^{-2}$ ), followed by the blue duiker (0.1-10.6 animals $\mathrm{km}^{-2}$ ), although absolute values were comparable in some cases. However, nocturnal surveys conducted in our study area (Kamgaing et al., 2018; own unpublished data) reported the converse, with density estimates of the blue duiker ( 59.8 animals $\mathrm{km}^{-2}$ ) at least six times as high as that of red duikers (9.0), brush-tailed porcupine (6.6), and tree pangolin (4.1). Jost Robinson et al. (2016) argued that such high density of the blue duiker occurred in forests where hunting is relatively recent.

To our knowledge, records of bushmeat harvests in southeast Cameroon also began in the 1990's (Dethier, 1995; Jeanmart, 1998; Muchaal and Ngandjui, 1999; Fimbel et al., 2000; Yasuoka,
2006, 2014; Bobo et al., 2015; Yasuoka et al., 2015). All these studies have clearly shown that in hunted forests, there is a spatial heterogeneity of human pressure and faunal assemblages. For example, the catch frequency of red duikers in snares can be 3-23 times as high as the catch frequency of the blue duiker, depending on human population density and the distance between the hunting area and the main road or settlement (Yasuoka, 2006). In remote zones (here located at $10-22 \mathrm{~km}$ from the main road), red river hogs were captured more than the blue duiker. However, in areas where hunting is more intense $(<10 \mathrm{~km}$ from the main road), red duikers were still the most hunted species, but the blue duiker was more prevalent than the red river hog. A village-based record of animal carcasses conducted 10 years later in the same site suggested the converse (Bobo et al., 2015), although differences were more moderate (blue duikers were captured 2.4 times as much as red duikers). A possible explanation of such patterns is that in areas under low or moderate human pressure, the density of red duikers is higher than that of blue duikers whereas the reverse is likely to be observed in areas under moderate or intense hunting pressure as suggested by Yasuoka et al. (2015).

However, the hunting strategy, rather than differences in population densities may explain why the capture frequency of less abundant species (e.g., red river hog) can exceed that of more abundant species such as red duikers and blue duikers in remote forest areas. Although the wire snare technology is known to be typically non-selective (Noss, 1998, 2000; Dounias, 2000), it allows the possibility to target in preference large body-sized animals such as red river hogs in areas where the signs of their activity are abundant. Snare hunters can target larger-sized preys by increasing the number of strands of the wire snares (Yasuoka, 2014; Dounias, 2016), by decreasing the sensitivity of the trigger mechanism, and by selecting a tougher support stick. Yet, the point that hunters can target in preference larger species by adjusting the snares design does not invalidate the use of prey composition as a reliable proxy of species abundance. Because larger preys are generally the first to be targeted, populations of these wildlife species are usually lower in forests near-human settlements. In conclusion, the influence of the previously described snaring setting on the global off take and on the structure of game composition may remain marginal, since it is seldom practiced in isolated areas where hunting remains infrequent and, other medium body-sized species relatively abundant.

\section{Similarities and Discrepancies in Wildlife Trends Between Hunters' Perception, Ecological Surveys and Bushmeat Records}

Previous studies have shown that larger species are usually sent to markets whereas most of the carcasses from smaller species are consumed in villages. Since hunting occurs both for consumption and trade in our study area, market demand can potentially affect the choice of prey (or prey composition) and species abundance. Even if this is the case for both $\mathrm{CHZ}$, perceptions of prey composition in our data may still reflect species abundance, 
TABLE 4 | Most common bushmeat species according to local hunters ( $n=169$ ) in $\mathrm{CHZ} 13$ and $\mathrm{CHZ} 14$ in 1952-1999 and according to studies conducted before 2000

\begin{tabular}{|c|c|c|c|c|}
\hline Game ranking & 1st & 2nd & 3rd & 4th \\
\hline \multicolumn{5}{|l|}{$\begin{array}{l}\text { Local perception in } \\
\text { both } \mathrm{CHZ}(\%)\end{array}$} \\
\hline Blue duiker & 65.7 & 9.5 & 8.4 & 3.9 \\
\hline Red duikers' group* & 26 & 48.5 & 50.9 & 32.9 \\
\hline $\begin{array}{l}\text { Brush-tailed } \\
\text { porcupine }\end{array}$ & 3 & 35.5 & 10.8 & 15.5 \\
\hline Red river hog & 3 & 3 & 9 & 18.1 \\
\hline Dung survey ${ }^{a}$ & Red duikers & Blue duiker & - & - \\
\hline \multirow[t]{2}{*}{$\begin{array}{l}\text { Village-based carcass } \\
\text { records }\end{array}$} & Blue duiker ${ }^{b}$ & Red duikers ${ }^{b}$ & $\begin{array}{l}\text { Brush-tailed } \\
\text { porcupine }^{b}\end{array}$ & - \\
\hline & Red duikers ${ }^{c}$ & Blue duiker ${ }^{\mathrm{C}}$ & Red river hogc & - \\
\hline \multirow[t]{2}{*}{$\begin{array}{l}\text { Camp-based carcass } \\
\text { records }\end{array}$} & Red duikers ${ }^{b c}$ & Blue duikerbc & $\begin{array}{l}\text { Brush-tailed } \\
\text { porcupine }^{b}\end{array}$ & - \\
\hline & & & Red river hog ${ }^{C}$ & \\
\hline
\end{tabular}

aEkobo (1998).

${ }^{b}$ Fimbel et al. (2000).

${ }^{c}$ Dethier (1995).

${ }^{*}$ Cephalophus callipygus, C. dorsalis, C. leucogaster, and C. nigrifrons.

Data from hunters who started hunting after 1999 were excluded.

given that exclusively hunters were interviewed. If interviews were administered away from hunting sites (e.g., in bushmeat markets), game composition, and abundance could have been biased in favor of larger species. Yet, this was not the case since in both CHZ, our data reflect well the spatial and temporal increases in small body-sized preys such as giant pouched rat and tree pangolin which are usually overlooked by market data.

Local knowledge of prey composition concurs with villagebased bushmeat records (Fimbel et al., 2000) for the two species most commonly killed in snare traps before the 2000's (Table 4). In fact, the majority of informants (66\%) all over the study area reported that as in 1952-2009, the blue duiker was the most common prey. Nearly half of the informants cited one of the red duiker species as the second (49\%) or the third (51\%) major game during the same period. However, Dethier (1995) reported a similar, though slightly higher share of red duikers compared to blue duikers (1.1 times lower) in village-based bushmeat data. Such similarity in the proportions of harvested red duikers and blue duikers may indicate that hunting pressure was considerably low or moderate during Dethier (1995)'s study and the density of red duikers excided (or was similar to) that of the blue duiker, as argued by Yasuoka et al. (2015).

As in 2015-2016 (Table 5), significantly higher proportions of hunters (94\% in $\mathrm{CHZ} 13$ vs. $92 \%$ in $\mathrm{CHZ} 14$ ) perceived that the blue duiker is the most common prey, as observed in villagebased carcass records (Yasuoka, 2006; Bobo et al., 2015) and in nocturnal transect surveys (Kamgaing et al., 2018).

However, the trends derived from dung surveys and bushmeat data collected in remote forest areas call into question the insights from interviews. Opinions on the two most abundant preys both before 2000 (Table 4) and in 2015-2016 (Table 5) controvert the trends observed in most camp-based carcass records (Dethier, 1995; Fimbel et al., 2000; Yasuoka, 2006) and dung surveys (Ekobo, 1998; Bobo et al., 2014), which actually suggest that red duikers, followed by the blue duiker are the most abundant. This apparent discrepancy is understandable acknowledging that in African rainforests, dung counts are likely to underestimate the density of forest ungulates, especially for the blue duiker (Waltert et al., 2006; Viquerat et al., 2012; Jost Robinson et al., 2016; Kamgaing et al., 2018). Another reason why the blue duiker instead was perceived as the most common prey may be that hunting is more frequent in forests around human settlements, where small body-sized games (generally the most resistant to hunting) are likely to be more common following the depletion of larger preys (Koerner et al., 2016). A third reason might be that in this study, informants were not asked to rank catch frequencies by forest area, but to sort them out globally. A future investigation of the former could explicitly highlight the differences between forest areas regarding animal abundance, since most informants reported that larger prey species are more abundant in 'remote' forest areas (own-unpublished data).

Studies based on dung counts in Southeast Cameroon (Table 6) suggest that since the 1990's red duikers, followed by blue duikers have always been the most abundant preys among the main bushmeat species (Ekobo, 1998; Bene Bene and Nzooh-Dongmo, 2005; Nzooh Dongmo et al., 2006; Bobo et al., 2014). However, this survey method is not practicable to estimating population densities for important bushmeat species such as the brush-tailed porcupine and tree pangolin (largely because they usually hide in burrows and trees, respectively) and thus, masks their potential importance among terrestrial mammals. Actually, high proportions of hunters $(71 \%$ in $\mathrm{CHZ}$ 13 vs. $58 \%$ in CHZ 14) agreed that as in 2015-2016, after the blue duiker, the brush-tailed porcupine was the most abundant prey (Table 5). If we ignore the records of the brush-tailed porcupine in the interview dataset (since transect sampling methods do not usually provide density estimates for this species), insights from hunters' perception would largely support those from nocturnal surveys and village- based carcass records that after the blue duiker, red duikers constitute the second most common prey. It is important to note that population densities provided for the brush-tailed porcupine and tree pangolin using direct observations along nocturnal line transects are likely to be underestimates for the same reasons mentioned above (own unpublished data), although both species are nocturnal (Table 6).

Our data on local knowledge suggest that snare hunting has potentially affected red duikers more severely than the blue duiker as expected from classic hunting models. Red duikers were the most common prey for $26 \%$ of the informants before 2000 (Table 4). However, only 5\% of the informants in CHZ 14 and $1 \%$ in CHZ 13 have respectively, cited a species from this group as being the most commonly killed by snares in 20152016 (Table 5). Similarly, nearly half of the informants (49\%) perceived red duikers as the second predominant prey during their beginnings in hunting. However, only 33\% in $\mathrm{CHZ} 14$ and $20 \%$ in CHZ 13 perceived that in 2015-2016, a species of this group still constitutes the second predominant game. In contrast to the red duikers, the blue duiker has maintained its population as the most common prey. In fact, the blue duiker 
TABLE 5 | Most abundant bushmeat species according to snare hunters in CHZ $13(n=105)$ and in CHZ $14(n=148)$ in $2015-2016$.

\begin{tabular}{|c|c|c|c|c|c|c|c|c|}
\hline \multirow[t]{2}{*}{ Game ranking by local hunters (\%) } & \multicolumn{2}{|c|}{ 1st } & \multicolumn{2}{|c|}{ 2nd } & \multicolumn{2}{|c|}{ 3rd } & \multicolumn{2}{|c|}{ 4th } \\
\hline & $\mathrm{CHZ} 13$ & $\mathrm{CHZ} 14$ & $\mathrm{CHZ} 13$ & $\mathrm{CHZ} 14$ & CHZ 13 & $\mathrm{CHZ} 14$ & $\mathrm{CHZ} 13$ & $\mathrm{CHZ} 14$ \\
\hline Blue duiker (Philantomba monticola) & 94.3 & 91.9 & 3.8 & 5.4 & 1 & 2.1 & 0.0 & 0.0 \\
\hline Red duikers' group (Cephalophus spp.)* & 1.0 & 5.4 & 20.0 & 33.1 & 39.8 & 77.6 & 47.3 & 58.1 \\
\hline Brush-tailed porcupine (Atherurus africanus) & 2.9 & 2.7 & 71.4 & 58.1 & 15.5 & 7.0 & 6.5 & 26.6 \\
\hline Giant pouched rat (Cricetomys emini) & 1.0 & 0.0 & 2.9 & 2.0 & 23.3 & 7.7 & 12.9 & 4.0 \\
\hline Tree pangolin (Phataginus tricupsis) & 0.0 & 0.0 & 0.0 & 0.7 & 19.4 & 2.1 & 28.0 & 2.4 .0 \\
\hline Red river hog (Potamochoerus porcus) & 0.0 & 0.0 & 0.0 & 0.0 & 0.0 & 3.5 & 3.2 & 6.5 \\
\hline
\end{tabular}

* "Red duikers" are constituted of Cephalophus callipygus, C. dorsalis, C. leucogaster and C. nigrifrons.

Data from hunters who stopped hunting before 2000 were excluded.

has always been the most common prey for at least $65 \%$ of the informants in this study. As for 2015-2016, this species was the most hunted for more than $91 \%$ of the informants in both CHZ. Other small body-sized species such as the brush-tailed porcupine, tree pangolin and giant pouched rat also became more common in catches, especially in CHZ 13, where human pressure is higher.

Insights from bushmeat harvest data in more heavily hunted areas also go in that direction. For example, Duda et al. (2017) analyzed the memory recalls of bushmeat harvest in Baka villages in Lomié and Messok districts, two towns, respectively, located at about 185 and $130 \mathrm{~km}$ west of our study area. The data from Duda et al. (2017) show that 32 species were reported as harvested. Among them, three species contributed up to $65 \%$ of the total number of catches, first the giant pouched rat (28\%), followed by the blue duiker (28\%), and brush-tailed porcupine (9\%). Primate species constituted $12 \%$ of the total off take. Another study led in Southwest Cameroon found that local hunters perceived the catch frequencies of rodents (brush-tailed porcupine, giant cane rat Tryonomis swinderianus, and giant pouched rat) to exceed that of the blue duiker and red duiker species (Wright and Priston, 2010). In conclusion, alterations of wildlife assemblages may be more recent and/or less severe in southeast Cameroon than in other regions like southwest Cameroon, where human population density is higher. Such patterns indicate differential levels of wildlife depletion between areas, as suggested in Gabon (Lahm, 1993; Koerner et al., 2016).

As mentioned above, the findings from Duda et al. (2017) indicate that despite their low individual body size, giant pouched rats can be captured as much as (or even more than) blue duikers (Table 6). In total $95 \%$ of the captures from that cavedwelling rodent was obtained by smoking individuals out of their burrows, whereas most blue duikers were killed using shotgun and snares. Although studies conducted in our research site and elsewhere in Southeast Cameroon do not report smoking out as a hunting method among local practices (Dethier, 1995; Jeanmart, 1998; Fimbel et al., 2000; Bobo et al., 2015; Yasuoka et al., 2015; but see Hagino, 2015), our field observations indicate that this technique is seldom practiced in our study site, and usually targets the brush-tailed porcupine. Smoking out of animals might emerge as a hunting method as other terrestrial/arboreal animals become relatively rare. Such insights indicate that
TABLE 6 | Most abundant bushmeat species based on data from ecological and ethnographic studies conducted in southeast Cameroon since the 2000's.

\begin{tabular}{|c|c|c|c|c|}
\hline $\begin{array}{l}\text { Game ranking from } \\
\text { ecological and } \\
\text { ethnographic } \\
\text { surveys }\end{array}$ & 1st & 2nd & 3rd & 4th \\
\hline $\begin{array}{l}\text { Interview about weekly } \\
\text { harvests (Lomié \& } \\
\text { Messok) }\end{array}$ & Giant rat & $\begin{array}{l}\text { Blue } \\
\text { duiker }\end{array}$ & $\begin{array}{l}\text { Brush- } \\
\text { tailed } \\
\text { porcupine }\end{array}$ & Mice \\
\hline $\begin{array}{l}\text { Dung survey } \\
\text { (Boumba-Bek \& Nki } \\
\text { NPs, CHZ 13 \& 14) })^{b, c, d}\end{array}$ & $\begin{array}{l}\text { Red } \\
\text { duikers }\end{array}$ & $\begin{array}{l}\text { Blue } \\
\text { duiker }\end{array}$ & I & / \\
\hline $\begin{array}{l}\text { Nocturnal surveys } \\
(\mathrm{CHZ} 13 \text { \& 14) }\end{array}$ & $\begin{array}{l}\text { Blue } \\
\text { duiker } \\
(38.9 ; \\
77.9)\end{array}$ & $\begin{array}{l}\text { Red } \\
\text { duikers } \\
(9.0)\end{array}$ & $\begin{array}{l}\text { Tree } \\
\text { pangolin } \\
(6.6)\end{array}$ & $\begin{array}{l}\text { Brush- } \\
\text { tailed } \\
\text { porcupine } \\
(4.4)\end{array}$ \\
\hline $\begin{array}{l}\text { Village-based carcass } \\
\text { records in } \mathrm{CHZ} 13^{\mathrm{e}}\end{array}$ & $\begin{array}{l}\text { Blue } \\
\text { duiker }\end{array}$ & $\begin{array}{l}\text { Red } \\
\text { duikers }\end{array}$ & $\begin{array}{l}\text { Giant } \\
\text { pouched } \\
\text { rat }\end{array}$ & $\begin{array}{l}\text { Tree } \\
\text { pangolin }\end{array}$ \\
\hline $\begin{array}{l}\text { Village-based carcass } \\
\text { records in } \mathrm{CHZ} 14^{\mathrm{e}}\end{array}$ & $\begin{array}{l}\text { Blue } \\
\text { duiker }\end{array}$ & $\begin{array}{l}\text { Red } \\
\text { duikers }\end{array}$ & $\begin{array}{l}\text { Brush- } \\
\text { tailed } \\
\text { porcupine }\end{array}$ & \\
\hline $\begin{array}{l}\text { Camp-based carcass } \\
\text { records in } \mathrm{CHZ} 13^{f}\end{array}$ & $\begin{array}{l}\text { Blue } \\
\text { duiker }\end{array}$ & $\begin{array}{l}\text { Red } \\
\text { duikers }\end{array}$ & $\begin{array}{l}\text { Brush- } \\
\text { tailed } \\
\text { porcupine }\end{array}$ & $\begin{array}{l}\text { Schweigger's } \\
\text { hinge-back } \\
\text { tortoise }\end{array}$ \\
\hline $\begin{array}{l}\text { Camp-based carcass } \\
\text { records in } \mathrm{CHZ} 14^{\dagger}\end{array}$ & $\begin{array}{l}\text { Red } \\
\text { duikers }\end{array}$ & $\begin{array}{l}\text { Red river } \\
\text { hog }\end{array}$ & Blue duiker & $\begin{array}{l}\text { Yellow- } \\
\text { backed } \\
\text { duiker }\end{array}$ \\
\hline
\end{tabular}

${ }^{a}$ Duda et al. (2017).

${ }^{b}$ Bene Bene and Nzooh-Dongmo (2005).

cNzooh Dongmo et al. (2006).

${ }^{d}$ Bobo et al. (2014).

e Bobo et al. (2015).

fYasuoka et al. (2015).

Data from hunters who stopped hunting before 2000 were excluded.

"Red duikers" are constituted of Cephalophus callipygus, C. dorsalis, C. leucogaster and C. nigrifrons.

*Numbers in brackets represent population density estimates (ind. $\mathrm{km}^{-2}$ ), calculated using Distance 6.2 software (Thomas et al., 2010). Kamgaing et al. (2018) provided published data on population density estimates for duikers and unpublished data for the tree pangolin and brush-tailed porcupine.

hunters may shift their hunting techniques depending on the relative abundance of animal species, as suggested by Fa and Peres (2001). 
However, untangling the effects of different hunting methods on the dynamics of game species was beyond the scope of the present study. Since our sampling approach focused on snare hunting, our analyses ignore the effects of other hunting methods such as shotgun and the contribution of other groups of prey species (e.g., arboreal primates) to the hunting profile. Nevertheless, our study still provides insightful findings on the spatial and temporal patterns in terrestrial bushmeat species in Southeast Cameroon, where wire snares remain the most widely used hunting tool and terrestrial mammals the main preys, as reported in other sites in the Congo basin (Wilkie and Carpenter, 1999; Fa and Peres, 2001; Fa et al., 2006; Dounias, 2016). We recommend analysis of the effects of hunting on prey profiles based on multiple hunting technologies, which allows reflectiveness of a more diverse range of game species.

In conclusion, local knowledge suggests a decline in the catch frequency of medium body-sized preys such as the red river hog, the yellow-backed duiker, and red duikers. This change is balanced with an increasing catch of small preys such as blue duikers, brush-tailed porcupines, tree pangolins, and giant pouched rats, which is congruent with global trends in species composition in hunting forests (Nasi et al., 2008; Fa and Brown, 2009; Koerner et al., 2016).

\section{Implication for Sustainable Management}

Stakeholders, especially the local peoples may more actively engage in participative management if a common understanding of the threats and trends in different species is met. This study has shown that local people have an acute awareness of wildlife changes, notably the declining populations of medium body-sized preys, coupled to an increasing share of smaller preys. Furthermore, local knowledge can supplement robust information on the abundance of wildlife populations, even for the taxa for which densities are difficult to estimate using more classic survey methods such as individual species of mediumsized duikers, medium-sized monkeys, red river hog, porcupines, and pangolins, important targets of bushmeat trade in WestCentral Africa.

Trends in species abundance from local knowledge and bushmeat records suggest some dichotomy regarding the protection level of different species of red duikers according to the norms of attribution of hunting quotas in Cameroon (Government of Cameroon, 1998). In fact, the categorization of animal species into different classes of protection has been set up inspired from the checklist of the Convention on International Trade of Endangered Species of Wild Fauna and Flora (CITES). Accordingly, the bay duiker and the Peters' duiker are in class B, which fix the species which are partially protected and for which hunting may be granted by a license. The black-fronted duiker and the white-bellied duiker are in class $C$ which includes species such as the blue duiker, some rodents and small carnivores that can be hunted moderately, without a hunting license. However, as previously suggested, among the red duiker species, the whitebellied duiker and the black-fronted duiker are by far the rarest.
It appears that a lower level of protection is attributed to the least abundant (and probably the most threatened) species of red duikers. This calls for the need to update this classification, at least in southeast Cameroon.

The general outlines that emerge from this study are: (1) insights from local people can rapidly help to identify coarse changes in prey abundance, even for the species for which population density is difficult to estimate using more conventional survey methods; (2) in southeast Cameroon and in forests regions with similar fauna, the bay duiker, and the Peters duiker are substantially more abundant than the white-bellied duiker and black-fronted duiker; (3) larger species are more represented in hunting catches in $\mathrm{CHZ} 14$ than in $\mathrm{CHZ} 13$, reflecting the spatial and temporal variations of hunting and animal abundance at the local level, as suggested in other hunting forests in Central Africa (van Vliet and Nasi, 2008; Koerner et al., 2016); and (4) the ranking of prey abundance by local hunters is likely to reflect more the faunal assemblages in anthropogenic forest mosaics, where most hunting activities are undertaken (Bobo et al., 2014) and is congruent with villagebased bushmeat records.

As far as we know, this study provides the most comprehensive survey combining spatial and temporal trends in bushmeat species in Cameroon to date. Overall, resource user-based interviews are useful to rapidly provide or supplement valuable information on wildlife population dynamics over years, especially in cases where ecological data may be absent. However, extrapolations of local perceptions over large geographical scales should be made with caution, since local knowledge is typically site specific (Gandiwa, 2012). The acute awareness of local hunters about the declining sizes of their largest prey populations suggests a potential for synergy with more effective participative management initiatives. We therefore, advocate an increase use of local knowledge to design new studies or to seek for adaptive management options, which are acceptable for local peoples and other stakeholders.

\section{AUTHOR CONTRIBUTIONS}

HY and TK conceived the methodology and analyzed the data. TK and ZD collected the field data. TK wrote original draft. All authors have reviewed, edited, and approved the current version of the manuscript.

\section{ACKNOWLEDGMENTS}

This research was supported by the JST-JICA SATREPS program (Projet Coméca), JSPS KAKENHI (Nos. 15H02598, 16H05661), Japan, and Institute for Agronomic Research and Rural Development (IRAD), Cameroon. Permission for field work was granted by the Ministry of Scientific Research and Innovation (MINRESI), Cameroon. We are grateful to the people of the study area for contributing this research and their warm hospitality. 


\section{REFERENCES}

Bene Bene, L., and Nzooh-Dongmo, Z. (2005). Suivi Ecologique dans le Parc National de Boumba Bek et sa Zone Périphérique: Données de Base sur la Dynamique des Populations de Grands et Moyens Mammifères et des Activités Anthropiques. Yaoundé: WWF; CCPO.

Bobo, K. S., Kamgaing, T. O. W., Kamdoum, E. C., and Dzefack, Z. C. B. (2015). Bushmeat hunting in southeastern Cameroon: magnitude and impact on duikers (Cephalophus spp.). Afr. Monogr. Suppl. Issue 51, 119-141. doi: 10.14989/197202

Bobo, K. S., Kamgaing, T. O. W., Ntumwel, B. C., Kagalang, D., Kengne, P. N. J., Ndengue, S. M. L., et al. (2014). Species richness, spatial distributions of large and medium-sized mammals in the northern periphery of Boumba-Bek National Park, Southeastern Cameroon. Afr. Monogr. Suppl. Issue 49, 91-114. doi: $10.14989 / 189626$

Bonebrake, T. C., Christensen, J., Boggs, C. L., and Ehrlich, P. R. (2010). Population decline assessment, historical baselines, and conservation. Conserv. Lett. 3, 371-378. doi: 10.1111/j.1755-263X.2010.00139.x

Brittain, S., Ngo Bata, M. N., De Ornellas, P. Milner-Gulland, E. J. and Rowcliffe, M. (2018). Combining local knowledge and occupancy analysis for a rapid assessment of the forest elephant Loxodonta cyclotis in Cameroon's timber production forests. Oryx 1-11. doi: 10.1017/S0030605317001569

Dethier, M. (1995). Etude Chasse. Projet ECOFAC-Composante Cameroun. Bruxelles: Groupement AGRECO-CTFT.

Dounias, E. (2000). "Le câble pris au piège de la conservation. Technologie du piégeage et production cynégétique chez les Mvae du sud Cameroun forestier," in L'Homme et la Forêt Tropicale, eds S. Bahuchet, D. Bley, H. Pagezy, and N. Vernazza-Licht (Châteauneuf de Grasse: Editions de Bergier), 281-300. Available online at: http://horizon.documentation.ird.fr/exl-doc/pleins_textes/ pleins_textes_7/b_fdi_55-56/010023531.pdf

Dounias, E. (2016). From subsistence to commercial hunting: technical shift in cynegetic practices among southern Cameroon forest dwellers during the 20th century. Ecol. Soc. 21:23. doi: 10.5751/ES-07946-210123

Duda, R., Gallois, S., and Reyes-Garcia, V. (2017). Hunting techniques, wildlife offtake and market integration. A perspective from individual variations among the Baka (Cameroon). Afr. Stud. Monogr. 38, 97-118. doi: 10.14989/225259

Egbe, S. E. (2001). The law, communities and wildlife management in Cameroon. Rural Dev. For. Netw. 25, 1-13. Available online at: www.odi.org/sites/odi.org. $\mathrm{uk} /$ files/odi-assets/publications- opinion-files/1216.pdf

Ekobo, A. (1998). Large Mammals and Vegetation Surveys in the Boumba-Bek and Nki Project Area. Yaoundé: WWF Cameroon, 123.

Fa, J. E., and Brown, D. (2009). Impacts of hunting on mammals in African tropical moist forests: a review and synthesis. Mammal. Rev. 39, 231-264. doi: 10.1111/j.1365-2907.2009.00149.x

Fa, J. E., Olivero, J., Farfán, M. A., Lewis, J., Yasuoka, H., Noss, et al. (2016). Differences between pygmy and non-pygmy hunting in congo basin forests. PLoS ONE 11:e0161703. doi: 10.1371/journal.pone.0161703

Fa, J. E., and Peres, C. A. (2001). "Game vertebrate extraction in African and Neotropical forests: an intercontinental comparison," in Conservation of Exploited Species, eds J. D. Reynolds, G. M. Mace, K.H. Redford, and J. G. Robinson (Cambridge: Cambridge University Press), 203-241.

Fa, J. E., Peres, C. A., and Meeuwig, J. (2002). Bushmeat exploitation in tropical forests: an intercontinental comparison. Conserv. Biol.16, 232-237. doi: 10.1046/j.1523-1739.2002.00275.x

Fa, J. E., Ryan, S. F., and Bell, D. J. (2005). Hunting vulnerability, ecological characteristics and harvest rates of bushmeat species in afrotropical forests. Biol. Conserv.121, 167-176. doi: 10.1016/j.biocon.2004.04.016

Fa, J. E., Seymour, S., Dupain, J., Amin, R., Albrechtsen, L., and Macdonald, D. (2006). Getting to grips with the magnitude of exploitation: bushmeat in the Cross-Sanaga Rivers Region, Nigeria and Cameroon. Biol. Conserv. 129, 497-510. doi: 10.1016/j.biocon.2005.11.031

Feer, F. (1988). Stratégies écologiques de deux espèces de bovidés sympatriques de la forêt sempervirente africaine (Cephalophus callipygus et C. dorsalis): influence du rythme d'activité. thèse Paris: Université Pierre et Marie Curie and Muséum national d'histoire naturelle, Paris, France.

Fimbel, C., Curran, B., and Usongo, L. (2000). "Enhancing the sustainability of duiker hunting through community participation and controlled access in the Lobeke region of southeastern Cameroon," in Hunting for Sustainability in
Tropical Forest, eds J. G. Robinson and E. L. Bennett (New York, NY: Colombia University Press), 356-374.

Gandiwa, E. (2012). Local knowledge and perceptions of animal population abundances by communities adjacent to the northern Gonarezhou National Park, Zimbabwe. Trop. Conserv. Sci. 5, 255-269. doi: $10.1177 / 194008291200500303$

Government of Cameroon (1998). Order No. 0565/A/MINEF/DFAP/SDF/SRC to Set the List of Animals of Classes A, B and C, the Distribution of Animal Species Whose Hunting is Authorized, as Well as the Hunting Quota Per Type of Hunting Permit. Available online at: http://ic.fsc.org/download.annex-bcameroon-species-classification-a-b-c-fr.433.pdf

Hagino, I. (2015). Ecology of Baka Hunter-Gatherers' children in Southeast Cameroon: nutritional status, physical activities, and daily behaviors (Ph.D. thesis). Hokkaido University, Sapporo, Japan.

Halle, B. (2000). Résumé des Données Socio-économiques du Milieu Rural au Sud-Est du Cameroun. Eschborn: Deutsche Gesellschaft fur Tchnische Zusammenarbeit (GTZ).

Hart, J. A. (2000). "Impact and sustainability of indigenous hunting in the Ituri Forest, Congo-Zaire: a comparison of hunted and unhunted duiker populations," in Hunting for Sustainability in Tropical Forests, eds J. G. Robinson and E. L. Bennett (New York, NY: Columbia University Press), 106-153.

Hyman, I. E., and Pentland, J. (1996). The role of mental imagery in the creation of false childhood memories. J. Mem. Lang. 35, 101-117. doi: 10.1006/jmla.1996.0006

Jeanmart, P. (1998). Tentative d'Élaboration d'un Plan de Gestion de la Chasse Villageoise dans la Réserve de Faune du Dja. Projet ECOFAC-Composante Cameroun. Groupement AGRECO- G.E.I.E. - BDPA-SCETAGRI - SECA CIRAD FORET. Bruxelles.

Jost Robinson, C. A., Zollner, P. A., and Kpanou, J. B. (2016). Night and day: evaluating transect methodologies to monitor duikers in the DzangaSangha Protected Areas, Central African Republic. Afr. J. Ecol. 55, 222-232. doi: 10.1111/aje.12344

Kahn, P. H. Jr., and Kellert, S. R. (eds) (2002). Children and Nature: Psychological, Sociocultural, and Evolutionary Investigations. Cambridge, MA: MIT Press.

Kamgaing, T. O. W., Bobo, K. S., Djekda, D., Azobou, K. B. V., Hamadjida, B. R., Balangounde, M. Y., et al. (2018). Population density estimates of forest duikers (Philantomba monticola and Cephalophus spp.) differ greatly between survey methods. Afr. J. Ecol. 56, 1-11. doi: 10.1111/aje.12518

Kingdon, J. (2015). The Kingdon Field Guide to African Mammals, 2nd Edn. London: Bloomsbury Publishing Plc.

Koerner, S. E., Poulsen, J. R., Blanchard, E. J., Okouyi, J., and Clark, C. J. (2016). Vertebrate community composition and diversity declines along a defaunation gradient radiating from rural villages in Gabon. J. Appl. Ecol. 54, 805-814. doi: $10.1111 / 1365-2664.12798$

Kümpel, N. F. (2006). Incentives for sustainable hunting of bushmeat in rio muni (Ph.D. thesis). Imperial College London, London, United Kingdom.

Lahm, S. A. (1993). "Utilization of forest resources and local variations of wildlife populations in northeastern Gabon," in Tropical Forests, People and Food: Biocultural Interactions and Applications to Development, eds C. M. Hladik, A. Hladik, O. F. Linares, H. Pagezy, A. Semple, and M. Hadley (Paris: UNESCO), 213-227.

Lahm, S. A. (2001). "Hunting and wildlife in northeastern Gabon: why conservation should extend beyond park boundaries," in African Rain Forest Ecology and Conservation, eds W. Weber, L. J. T. White, A. Vedder, and N. Naughton-Treves (New Haven, CT: Yale University Press), 344-354.

Letouzey, R. (1985). Carte Phytogéographique du Cameroun au 1:500000. Toulouse: Institut de la Recherche Agronomique (Herbier National).

Mendelson, S., Cowlishaw, G., and Rowcliffe, J. M. (2003). Anatomy of a bushmeat commodity chain in Takoradi, Ghana. J. Peasant. Stud. 31, 73-100. doi: $10.1080 / 030661503100016934$

Muchaal, K. P., and Ngandjui, G. (1999). Impact of village hunting on wildlife populations in the western Dja Reserve, Cameroon. Conserv. Biol. 13, 385-396. doi: 10.1046/j.1523-1739.1999.013002385.x

Nash, H. C., Wong, M. H. G., and Turvey, S. T. (2016). Using local ecological knowledge to determine status and threats of the Critically Endangered Chinese pangolin (Manis pentadactyla) in Hainan, China. Biol. Conserv. 196, 189-195. doi: 10.1016/j.biocon.2016.02.025 
Nasi, R., Brown, D., Wilkie, D., Bennett, E., Tutin, C., van Tol, G., et al. (2008). Conservation and Use of Wildlife-Based Resources: the Bushmeat Crisis. Secretariat of the Convention on Biological Diversity, Montreal, and Center for International Forestry Research (CIFOR), Bogor. Technical Series no. 33, 50. Available online at: https://www.cbd.int/doc/publications/cbd-ts-33-en.pdf

Noss, A. J. (1998). The impacts of cable snare hunting on wildlife population in the forest of Central African Republic. Conserv. Biol. 12, 390-398. doi: 10.1046/j.1523-1739.1998.96027.x

Noss, A. J. (2000). "Cable snares and nets in the Central African Republic," in Hunting for Sustainability in Tropical Forests, eds J. G. Robinson and E. L. Bennett (New York, NY: Columbia University Press), 282-304.

Nzooh Dongmo, Z. L., Kouob Begne, S., Annong, V., Bassama, C., Fouda, E., and Mahop, J. P. (2006). Suivi Ecologique dans le Parc National de Nki et sa Zone Périphérique: Donneés de base sur la Dynamique des Populations de Grands et Moyens Mammiféres et des Activités Anthropiques. Yaoundé: WWF/CCPO/JSEFP.

Pan, Y., Cunningham, A. A., and Milner-Gulland, E. J. (2015). Using local ecological knowledge to assess the status of the critically endangered Chinese giant salamander Andrias davidianus in Guizhou Province, China. Oryx 50, 257-264. doi: 10.1017/S0030605314000830

Papworth, S. K., Rist, J., Coad, L., and Milner-Gulland, E. J. (2009). Evidence for shifting baseline syndrome in conservation. Conserv. Lett. 2, 93-100. doi: 10.1111/j.1755-263X.2009.00049.x

Pauly, D. (1995). Anecdotes and the shifting baseline syndrome of fisheries. Trends Ecol. Evol. 10:430. doi: 10.1016/S.0169-5347(00)89171-5

R Core Team (2016). R: A Language and Environment for Statistical Computing. Vienna: R Foundation for Statistical Computing. Available online at: https:// www.R-project.org/

Robinson, J. G., and Redford, K. H. (1991). Sustainable Harvest of Neotropical Forest Animals. Chicago, IL: University of Chicago Press.

Roediger, H. L., Jacoby, J. D., and McDermott, K. B. (1996). Misinformation effects in recall: creating false memories through repeated retrieval. J. Mem. Lang. 35, 300-318. doi: 10.1006/jmla.1996.0017

Rosin, C., and Poulsen, J. R. (2016). Hunting-induced defaunation drives increased seed predation and decreased seedling establishment of commercially important tree species in an Afrotropical forest. For. Ecol. Manag. 382, 206-213. doi: 10.1016/j.foreco.2016.10.016

Shetler, B. J. (2007). Imagining Serengeti: A History of Landscape Memory in Tanzania From Earliest Times to the Present (New African Histories). Athens, $\mathrm{OH}$ : Ohio University Press.

Social Research Association (2003). Ethical Guidelines. Available online at: http:// the-sra.org.uk/wp-content/uploads/ethics03.pdf (accessed November 9, 2018).

Taylor, G., Scharlemann, J. P. W., Rowcliffe, M., Kümpel, N., Harfoot, M. B. J., Fa, J. E., et al. (2015). Synthesising bushmeat research effort in West and Central Africa: a new regional database. Biol. Conserv. 181, 199-205. doi: 10.1016/j.biocon.2014.11.001

Terborgh, J., Nunez-Iturri, G., Pitman, N. C. A., Valverde, F. H. C., Alvarez, P., Swamy et al. (2008). Tree recruitment in an empty forest. Ecology 89, 1757-1768. doi: 10.1890/07-0479.1

Thomas, L., Buckland, S. T., Rexstad, E. A., Laake, J. L., Strindberg, S., Hedley, S. L., et al. (2010). Distance software: design and analysis of distance sampling surveys for estimating population size. J. Appl. Ecol. 47, 5-14. doi: $10.1111 / j .1365-2664.2009 .01737 . \mathrm{x}$ van Vliet, N., Muhindo, J., Nyumu, J. K., Mushagalusa, O., and Nasi, R. (2018). Mammal depletion processes as evidenced from spatially explicit and temporal local ecological knowledge. Trop. Conserv. Sci. 11, 1-15. doi: $10.1177 / 1940082918799494$

van Vliet, N., and Nasi, R. (2008). Why do models fail to assess properly the sustainability of duiker (Cephalophus spp.) hunting in Central Africa? Oryx 42, 392-399. doi: 10.1017/S0030605308000288

van Vliet, N., Nasi, R., Emmons, L., Feer, F., Mbazza, P., and Bourgarel, M. (2007). Evidence for the local depletion of bay duiker Cephalophus dorsalis, within the Ipassa Man and Biosphere Reserve, north-east Gabon. Afr. J. Ecol. 45, 440-443. doi: 10.1111/j.1365-2028.2007. 00783.x

van Vliet, N., Zundel, S., Miquel, C., Tarbelet, P., and Nasi, R. (2008). Distinguishing dung from blue, red and yellow-backed duikers through noninvasive genetic techniques. Afr. J. Ecol. 46, 411-417. doi: 10.1111/j.1365-2028.2007.00879.x

Viquerat, S. M. A., Bobo, K. S., Müller, M., Kiffner, C., and Waltert, M. (2012). Estimating forest duiker (Cephalophinae) density in Korup National Park: a case study on the performance of three line transect methods. Afr. J. Wildl. Res. 42, 1-10. doi: 10.3957/056.042.0110

Waltert, M., Heber, S., Riedelbauch, S., Lien, J. L., and Muhlenberg, M. (2006). Estimates of blue duiker (Cephalophus monticola) densities from diurnal and nocturnal line transects in the Korup region, south-western Cameroon. Afr. J. Ecol. 44, 290-292. doi: 10.1111/j.1365-2028.2006. 00631.x

Wilkie, D. S., and Carpenter, J. F. (1999). Bushmeat hunting in the Congo Basin: an assessment of impacts and options for mitigations. Biodivers. Conserv. 8 , 927-955. doi: 10.1023/A:1008877309871

Wright, J. H., and Priston, N. E. C. (2010). Hunting and trapping in Lebialem division, Cameroon: bushmeat harvesting practices and human reliance. Endanger. Species Res. 11, 1-12. doi: 10.3354/esr00244

Yasuoka, H. (2006). The sustainability of duiker (Cephalophus spp.) hunting for the Baka hunter-gatherers in southeastern Cameroon. Afr. Stud. Monogr. Suppl. Iss. 33, 95-120. doi: 10.14989/68473

Yasuoka, H. (2014). Snare hunting among Baka hunter-gatherers: implications for sustainable wildlife management. Afr. Stud. Monogr. Suppl. Iss. 49, 115-136. doi: $10.14989 / 189625$

Yasuoka, H., Hirai, M., Kamgaing, T. O. W., Dzefack, Z. C. B., Kamdoum, E. C., and Bobo, K. S. (2015). Changes in the composition of hunting catches in southeastern Cameroon: a promising approach for collaborative wildlife management between ecologists and local hunters. Ecol. Soc. 20:12. doi: 10.5751/ES-08041-200425

Conflict of Interest Statement: The authors declare that the research was conducted in the absence of any commercial or financial relationships that could be construed as a potential conflict of interest.

Copyright (c) 2019 Kamgaing, Dzefack and Yasuoka. This is an open-access article distributed under the terms of the Creative Commons Attribution License (CC BY). The use, distribution or reproduction in other forums is permitted, provided the original author(s) and the copyright owner(s) are credited and that the original publication in this journal is cited, in accordance with accepted academic practice. No use, distribution or reproduction is permitted which does not comply with these terms. 